\title{
STUDY OF MANDIBULAR RAMUS AS PREDICTOR OF SEX
}

\author{
Shivaprakash S ${ }^{1}$, Ashok K R *2. \\ ${ }^{1}$ Assistant Professor, Department of Anatomy, JSS Medical College, Mysuru, Karnataka, India. \\ ${ }^{* 2}$ Assistant Professor, Department of Anatomy, BGS Global Institute of Medical Sciences, Bengaluru, \\ Karnataka, India.
}

\section{ABSTRACT}

Background: Methods based on measurements and morphometry are accurate and can be used in determination of sex. Even the bony remains like mandibular ramus can be used to predict the sex of the individual which will be of help for forensic experts. Morphometry of mandibular ramus will also be of importance for anthropologists, anatomists and prosthetists.

Materials and Methods: Coronoid height, maximum ramus breadth, minimum ramus breadth and maximum ramus height was measured in 200 adult cadavers.

Results: The coronoid height varied from $42.02 \mathrm{~mm}$ to $68.46 \mathrm{~mm}$ in males and it varied from $40.08 \mathrm{~mm}$ to 66.76 $\mathrm{mm}$ in females. The maximum ramus breadth in male mandible varied from $28.84 \mathrm{~mm}$ to $42.28 \mathrm{~mm}$ and in females it varied from $27.44 \mathrm{~mm}$ to $41.42 \mathrm{~mm}$. The minimum ramus breadth in males varied from $21.92 \mathrm{~mm}$ to $36.80 \mathrm{~mm}$, in females it varied from $17 \mathrm{~mm}$ to $34.26 \mathrm{~mm}$. The maximum ramus height in males varied from 47.76 $\mathrm{mm}$ to $68.64 \mathrm{~mm}$ and in females it varied from $42.56 \mathrm{~mm}$ to $69.56 \mathrm{~mm}$.

Conclusion: All the parameters measured were higher in males than females. Comparison studies revealed that the South Indian parameters were lesser than Thais, Croatians and Africans.

KEYWORDS: Mandibular ramus, Coronoid height, Ramus height, Ramus breadth.

Address for Correspondence: Dr Ashok. K. R, Assistant Professor, Department of Anatomy, BGS Global Institute of Medical Sciences, No 67, Dr Vishnuvardhan Road, Kengeri, Bengaluru, Karnataka - 560060, India. Phone No: +919743006759 E-Mail: hingyake@gmail.com

Access this Article online

Quick Response code

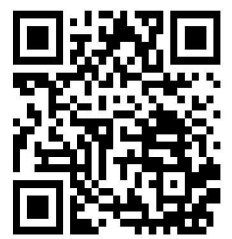

DOI: $10.16965 /$ ijar.2018.364

\begin{tabular}{|c|c|c|}
\hline \multicolumn{3}{|c|}{ Journal Information } \\
\hline 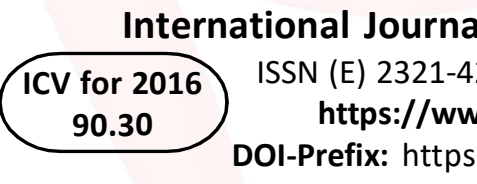 & $\begin{array}{l}\text { Anatomy and Res } \\
\text { ISSN (P) 2321-8967 } \\
\text { hr.org/ijar.htm } \\
\text { doi.org/10.16965/ijar }\end{array}$ & (cc) $\overline{\mathrm{BT}-\mathrm{No}-\mathrm{si}}$ \\
\hline \multicolumn{3}{|c|}{ Article Information } \\
\hline $\begin{array}{l}\text { Received: } 21 \text { Aug } 2018 \\
\text { Peer Review: } 21 \text { Aug } 2018 \\
\text { Revised: None }\end{array}$ & $\begin{array}{l}\text { Accepted: } 03 \text { Oct } \\
\text { Published (O): } 05 \\
\text { Published (P): } 05\end{array}$ & $\begin{array}{l}8 \\
2018 \\
2018\end{array}$ \\
\hline
\end{tabular}

INTRODUCTION

The identification of sex from human remains is of fundamental importance in criminal investigations as well as in the identification of missing persons and in attempts at reconstructing the lives of ancient populations [1]. Sex identification is of significance in cases of mass fatality incidents where bodies are damaged beyond recognition and it depends largely on the available parts of skeleton [2]. Sex can beestablished from a gross examination of the skeleton using either metric or morphological techniques. They should be used in conjunction to produce the most accurate and complete assessment of sexual dimorphism. Metric methods of sex determination is beneficial when compared to morphological methods, because they rely on standard landmarks [3].

The skeletal components most often investigated for gender determination are the pelvis and the skull. Pelvis helps to accurately determine the sex in $95 \%$ cases, skull alone in $90 \%$ cases, both 
pelvis and skull in $98 \%$ and long bones in $80 \%$ cases [4].

Since a complete pelvis and skull is not always present; it is essential to obtain as much detail as possible from less obvious components. The Mandible is appropriate for the study because it is the most durable facial bone, it retains its shape better than others and it is most dimorphic. Ramus of mandible and mandibular condyle is considered most dimorphic. [5].

Numerous studies have clearly demonstrated that skeletal characteristics vary by population and that there is a need for population specific standards for sex determination [6]. Most of the parameters in Indian mandibles differ markedly from other ethnic groups. Such a racial variation is expected to exist because of genetic makeup and social habits of different races.

The present study was conducted with an aim to get more information about Mandibular ramus in South Indian population and to use it as a predictor for sex determination.

\section{MATERIALS AND METHODS}

The study was conducted on 200 adult mandibles, which were obtained from Kasturba Medical College, Mangalore and Manipal, JSS Medical College, Mysore. The damaged mandibles, mandibles presenting significant alveolar resorption due to excessive tooth loss were excluded from the study.

All the measurements were taken in millimeters and degrees using sliding vernier calipers, protractor and measuring scale.

The randomly numbered bone was subjectively sexed, independently, using morphological features given in the standard textbooks of Anatomy, Anthropometry, and Forensic science.

The following measurements of mandibular ramus were recorded on randomly numbered mandibles (figure 1 and 2):

1. Coronoid Height: Distance between superior most point on coronoid process and basal border of the mandibular body.

2.Maximum Ramus Breadth: Distance between the most anterior point on them mandibular ramus and a line connecting the most posterior point on the condyle and the angle of the jaw.
3.Minimum Ramus breadth: It is the smallest breadth of the mandibular ramus and is measured perpendicularly to the height of ramus.

4. Maximum Ramus height: Direct distance from the highest point on the mandibular condyle to gonion.

Fig. 1: Coronoid height and maximum ramus height.

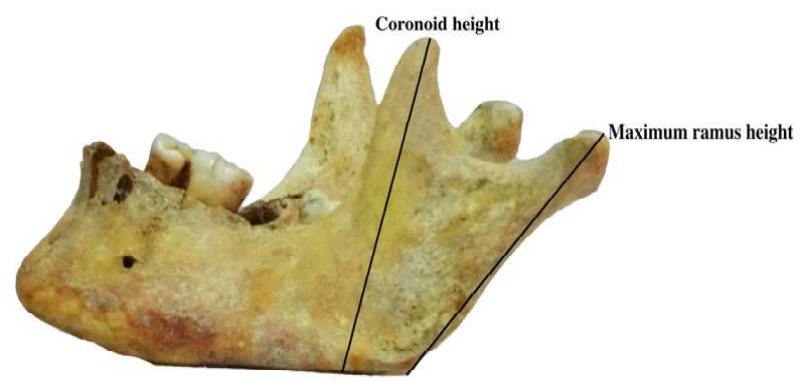

Fig. 2: Maximum and minimum ramus breadth.

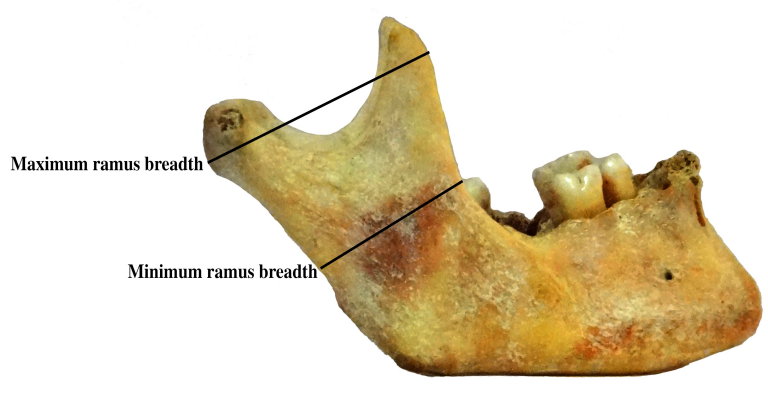

\section{RESULTS AND DISCUSSION}

There has been many quantitative studies describing the morphometry of mandible in different population, but the literature regarding Indian mandibles were very few. This study is an effort to know more about mandibular morphometry in South Indian mandibles and its usefulness in determining the sex. Since the literature says that anatomical variation of mandible exists between different populations, the different parameters of the present study has been compared with the parameters of mandibles in foreign studies.

The coronoid height in males varied from 42.02 $\mathrm{mm}$ to $68.46 \mathrm{~mm}$ with an average of $58.20 \pm$ $4.70 \mathrm{~mm}$. In females it varied from $40.08 \mathrm{~mm}$ to $66.76 \mathrm{~mm}$, with an average of $55.59 \pm 5.25 \mathrm{~mm}$. It was observed that the coronoid height in males was $2.61 \mathrm{~mm}$ higher than that of the females and the differences were statistically very highly significant $(p=0.000)$. [Table 1 ]

The mean coronoid height of males and females $(58.20 \mathrm{~mm}$ and $55.59 \mathrm{~mm}$ ) in the present study 
is much lesser than the values obtained by $\mathrm{N}$. Ongkana on Thai mandibles $(64.8 \mathrm{~mm}$ in males and $59 \mathrm{~mm}$ in females) [7] and radiographic values obtained by Tejavathi Nagaraj et al (69.13 $\mathrm{mm}$ in males and 65.88 in females) [8]. In all these studies it was observed that, the coronoid height is higher in males than in females and the differences were very highly significant $(p<0.001)$ on statistical analysis. Coronoid height alone is considered as single best parameter to predict sex with an accuracy of $74.1 \%$ [9].

The maximum ramus breadth in male mandible varied from $28.84 \mathrm{~mm}$ to $42.28 \mathrm{~mm}$ with an average of $35.82 \pm 3.09 \mathrm{~mm}$. In females it varied from $27.44 \mathrm{~mm}$ to $41.42 \mathrm{~mm}$, with an average of $34.19 \pm 3.17 \mathrm{~mm}$. It was been observed that the maximum ramus breadth in males was $1.63 \mathrm{~mm}$ broader than that of the females and the differences were statistically very highly significant $(p=0.000)$. [Table 1]

The mean maximum ramus breadth of males and females $(35.82 \mathrm{~mm}$ and $34.17 \mathrm{~mm}$ ) in the present study is lesser than the values obtained by Vodanovic $M$ on Croatian mandibles (44.20 $\mathrm{mm}$ in males and $41.23 \mathrm{~mm}$ in females) [10] and lesser than values obtained by Tejavathi Nagaraj et al ( $40.55 \mathrm{~mm}$ in males and 39.44 in females) [8]. In all these studies it was observed that, the maximum ramus breadth is greater in males than in females and the differences were very highly significant $(p<0.001)$ on statistical analysis.

The minimum ramus breadth in males varied from $21.92 \mathrm{~mm}$ to $36.80 \mathrm{~mm}$ with an average of $28.89 \pm 2.95 \mathrm{~mm}$. In females it varied from 17 $\mathrm{mm}$ to $34.26 \mathrm{~mm}$, with an average of 27.49 $\pm 3.18 \mathrm{~mm}$. Minimum ramus breadth in males was $1.40 \mathrm{~mm}$ broader than that of the females and the differences were statistically very highly significant $(p=0.000)$. [Table 1]
The mean minimum ramus breadth in males and females $(28.89 \mathrm{~mm}$ and $27.49 \mathrm{~mm}$ ) in the present study is lesser than that of the study done by Vodanovic on Croatians $(31.26 \mathrm{~mm}$ in males and $28.36 \mathrm{~mm}$ in females) [10], $\mathrm{N}$. Ongkana on Thais (32.8 $\mathrm{mm}$ in males and 31.4 $\mathrm{mm}$ in females) [7] and and lesser than values obtained by Tejavathi Nagaraj et al $(33.50 \mathrm{~mm}$ in males and $32.63 \mathrm{~mm}$ in females) [8].

In all these studies it was observed that the minimum ramus breadth is greater in males than the females and the differences were highly significant $(p<0.01)$ on statistical analysis.

The maximum ramus height in males varied from $47.76 \mathrm{~mm}$ to $68.64 \mathrm{~mm}$ with an average of 59.21 $\pm 4.69 \mathrm{~mm}$. In females it varied from $42.56 \mathrm{~mm}$ to $69.56 \mathrm{~mm}$, with an average of $55.55 \pm 4.93$ $\mathrm{mm}$. Maximum ramus height in males was 3.66 $\mathrm{mm}$ taller than that of the females, and the differences were statistically very highly significant $(p=0.000)$. [Table 1 ]

The mean maximum ramus height in males and females $(59.21 \mathrm{~mm}$ and $55.55 \mathrm{~mm}$ ) in the present study is lesser than that of the study done by Mbajiorgu on Zimbabweans $(59.8 \mathrm{~mm}$ in males and $61.3 \mathrm{~mm}$ in females) [11], Vodanovic on Croatians $(67.42 \mathrm{~mm}$ in males and $61.46 \mathrm{~mm}$ in females) [10] and $\mathrm{N}$. Ongkana on Thais $(68.1 \mathrm{~mm}$ in males and $62.6 \mathrm{~mm}$ in females) [7].

Except in the study done by Mbajiorgu on Zimbabweans, all other studies showed that the maximum ramus height is greater in males than in females, but in the observation done by Mbajiorgu ramus height was more in females than in males. All these studies showed very highly significant differences between the males and females $(p<0.001)$ on statistical analysis.

Table 1: Comparative statistics

\begin{tabular}{|c|c|c|c|c|}
\hline Parameter & Sex & Range & $\begin{array}{c}\text { Mean } \pm \text { Standard } \\
\text { deviation }\end{array}$ & $p$ value \\
\hline \multirow{2}{*}{ Coronoid height } & Male & $42.02-68.46$ & $58.20 \pm 4.70$ & \multirow{2}{*}{$\begin{array}{c}\mathrm{P}=0.000 \text { Very highly } \\
\text { significant }\end{array}$} \\
\hline & Female & $40.08-66.78$ & $55.59 \pm 5.25$ & \\
\hline \multirow{2}{*}{$\begin{array}{l}\text { Maximum ramus } \\
\text { breadth }\end{array}$} & Male & $28.84-42.28$ & $35.82 \pm 3.09$ & \multirow{2}{*}{$\begin{array}{c}P=0.000 \text { Very highly } \\
\text { significant }\end{array}$} \\
\hline & Female & $27.44-41.42$ & $34.19 \pm 3.17$ & \\
\hline \multirow{2}{*}{$\begin{array}{l}\text { Minimum ramus } \\
\text { breadth }\end{array}$} & Male & $21.92-36.8$ & $28.89 \pm 2.95$ & \multirow{2}{*}{$\begin{array}{c}P=0.001 \text { Very highly } \\
\text { significant }\end{array}$} \\
\hline & Female & $17-34.26$ & $27.49 \pm 3.18$ & \\
\hline \multirow{2}{*}{$\begin{array}{c}\text { Maximum ramus } \\
\text { height }\end{array}$} & Male & $47.76-68.64$ & $59.21 \pm 4.69$ & \multirow{2}{*}{$\begin{array}{c}P=0.000 \text { Very highly } \\
\text { significant }\end{array}$} \\
\hline & Female & $42.56-69.56$ & $55.55 \pm 4.93$ & \\
\hline
\end{tabular}




\section{CONCLUSION}

Mandibular ramus was studied to appreciate its value as a predictor of sex. Coronoid height, Maximum ramus breadth, minimum ramus breadth and maximum ramus height was measured, statistically analysed and compared with previous studies. All the parameters measured were higher in males than females. Comparison studied revealed that the South Indian parameters were lesser than Thais, Croatians and Africans.

These morphometric findings on mandibular ramus can be used to predict the sex of the bony remains which will be of help for forensic experts, the study also emphasizes the interpopulation variation which will be of importance for anthropologists, anatomists and prosthetists.

\section{Conflicts of Interests: None}

\section{REFERENCES}

[1]. Iscan MY, Kedici PS. Sexual variation in bucco-lingual dimensions in Turkish dentition. Forensic Sci Int 2003;137(2):160-4.

[2]. Raj JD, Ramesh S. Sexual dimorphism in mandibular ramus of south Indian population. Antrocom Online Journal of Anthropology 2013;9:253-258.

[3]. Byers S. Introduction to forensic anthropology. Boston: Allyn and Bacon; 2002.

[4]. Krogman WM, Iscan MY. The human skeleton in forensic medicine. $2^{\text {nd }}$ ed. Springfield: Charles C. Thomas; 1986;189-200.
[5]. Annamalai Ponnuswamy Indira, Archana Markande Maria P David. Mandibular Ramus: An indicator for sex determination - A digital radiographic study. J Forensic Dent Sci. 2012. Jul - Dec;4 (2):58-62.

[6]. Steyn M, Iscan MY. Sexual dimorphism in the crania and mandibles of South African whites. Forensic Sci Int 1998; 98(1): 9-16.

[7]. Nutcharian Ongkana, Paiwan Sudwan. Gender differences in Thai mandibles using metric analysis. Chiang Mai Med J 2009;48(2):43-8.

[8]. Tejavathi Nagaraj, Leena James, Sita Gogula, Noori Ghouse, Haritma Nigam, C. K. Sumana. Sex determination by using mandibular ramus: A digital radiographic study. Journal of Medicine, Radiology, Pathology and Surgery. 2017;4:5-8.

[9]. Vineeta Saini, Rashmi Srivastava, Rajesh K Raj, Satya N Shamal, Tej B Singh, Sunil K Tripathi. Mandibular Ramus: An indicator for sex in fragmentary mandible. Journal of Forensic sciences. Jan 2011;56 (1): S13 - S16.

[10]. Vodanovic M, Dumancic J, Demo J. Determination of sex by discriminant function analysis of mandibles from two Croatian archaeological sites. Acta stomatol croat 2006;40(3):263-77.

[11]. Mbajiorgu EF, Zivanovich S, Asala SA, Mavera GA. A pilot study of mandibular angle in black Zimbabweans. Cent Afr J Med 1996;42(10): 285-7.

How to cite this article:

Shivaprakash S, Ashok K R. STUDY OF MANDIBULAR RAMUS AS

PREDICTOR OF SEX. Int J Anat Res 2018;6(4.2):5869-5872. DOI: 10.16965/ijar.2018.364 